\title{
INHIBITION OF $\left[{ }^{3} \mathrm{H}\right]$-DIHYDROALPRENOLOL BINDING TO RAT CARDIAC MEMBRANES BY VARIOUS $\beta$-BLOCKING AGENTS
}

\section{P. CHENIEUX-GUiChENEY, J.P. DAUSSE, P. MEYER \& H. SCHMITT*}

Physiologie \& Pharmacologie, INSERM U.7, Hôpital Necker, 161, rue de Sèvres, 75015 Paris and "Département de Pharmacologie, UER des Cordeliers, Rue de l'Ecole de Médecine, 75006 Paris, France.

1 Binding of $\left[{ }^{3} \mathrm{H}\right]$-dihydroalprenolol $\left(\left[{ }^{3} \mathrm{H}\right]-\mathrm{DHA}\right)$ to rat cardiac membranes was rapid and reversible $\left(k_{1}=0.633-0.701 \times 10^{6} \mathrm{M}^{-1} \mathrm{~s}^{-1}\right.$ and $\left.k_{-1}=0.0017-0.0043 \mathrm{~s}^{-1}\right)$.

$2\left[{ }^{3} \mathrm{H}\right]-$ DHA bound to a single class of binding sites with an equilibrium dissociation constant $\left(K_{\mathrm{d} 25^{\circ} \mathrm{C}}\right)$ of $5.7 \pm 1.1 \times 10^{-9} \mathrm{M}$.

3 This binding was specific and the order of potency of adrenoceptor agonists in competing for the binding sites was $(-)$-isoproterenol $>( \pm)$-isoproterenol $>(+)$-isoproterenol $>(-)$-adrenaline $>(-)$-noradrenaline. This was in agreement with the $\beta_{1}$ nature of the cardiac $\beta$-receptors. 4 Cardioselective $\beta$-blockers (i.e. metoprolol, acebutolol and practolol) were shown to have lower binding site affinities, when compared to other blockers. This may be related to steric hindrance by the side-chain at the aromatic end of these molecules.

\section{Introduction}

Successful biochemical labelling of $\beta$-adrenoceptor sites has recently been obtained in avian (Brown, Gardner \& Aurbach, 1976), amphibian (Lefkowitz \& Williams, 1977) and mammalian tissues (Alexander, Williams \& Lefkowitz, 1975). In the present study, $\left[{ }^{3} \mathrm{H}\right]$-dihydroalprenolol, one of the better $\beta$-adrenoceptor antagonist radioligands, was used to identify $\beta$-adrenoceptor sites in membranes prepared from rat heart. On the basis of this characterization, thirteen $\beta$-adrenoceptor blocking agents were studied for their effects on $\left[{ }^{3} \mathrm{H}\right]$-dihydroalprenolol binding to cardiac membranes. It was noteworthy that the observed affinities were in good agreement with reported results of pharmacological studies (Kaumann \& Birnbaumer, 1974; Harms, 1976). These observations and the technical simplicity of the binding studies reported here, suggest that they may be a useful tool in the screening of new drugs reacting with $\beta$-receptors.

\section{Methods}

\section{Membrane preparation.}

Membranes were prepared from cardiac ventricles of male Wistar rats $(200-250 \mathrm{~g})$ by a modification of the method of Harden, Wolfe \& Molinoff (1976). In brief, the ventricles were first homogenized in ice-cold buffer $\left(0.25 \mathrm{M}\right.$ sucrose, $1 \mathrm{~mm} \mathrm{MgCl}_{2}, 0.05 \%$ ascorbic acid, $5 \mathrm{~mm}$ Tris- $\mathrm{HCl}, \mathrm{pH} 7.5$ ) with a type TP 18-10 Ultra-Turax homogenizer at maximum speed and centrifuged at $17,000 \mathrm{~g}$ for $15 \mathrm{~min}$ in a Sorvall RC 2B centrifuge. The pellet, resuspended in Tris-buffer $1.72 \mathrm{M}$ with respect to sucrose, was made the lower layer of a two layer sucrose gradient, the upper being $0.2 \mathrm{M}$ in the Tris-buffer described. After centrifugation at $100,000 \mathrm{~g}$ for $90 \mathrm{~min}$, membranes were collected at the interface of the two sucrose layers and diluted for binding studies. Approximately $10 \mathrm{mg}$ of membrane protein were obtained from $1 \mathrm{~g}$ of heart ventricles.

\section{Binding assay}

$\left[{ }^{3} \mathrm{H}\right]$-dihydroalprenolol $\left(\left[{ }^{3} \mathrm{H}\right]-\mathrm{DHA}\right)$ and myocardial membranes $(200-300 \mu \mathrm{g})$ were incubated for $30 \mathrm{~min}$ at $25^{\circ} \mathrm{C}$, with and without the addition of $1 \times 10^{-5} \mathrm{M}$ alprenolol, in $50 \mathrm{~mm}$ Tris- $\mathrm{HCl}$ buffer containing $\mathrm{MgCl}_{2} 10 \mathrm{mM}$ and ascorbic acid $0.05 \%$, to make a final volume of $150 \mu \mathrm{l}$. In competitive binding experiments, the competing agent was added directly to the incubation mixture. Incubations were stopped by dilution of $100 \mu \mathrm{l}$ incubation aliquots with $2 \mathrm{ml}$ of incubation buffer $\left(+4^{\circ} \mathrm{C}\right)$ followed by filtration through Whatman GF/C glass fibre filters. Filters were rapidly 

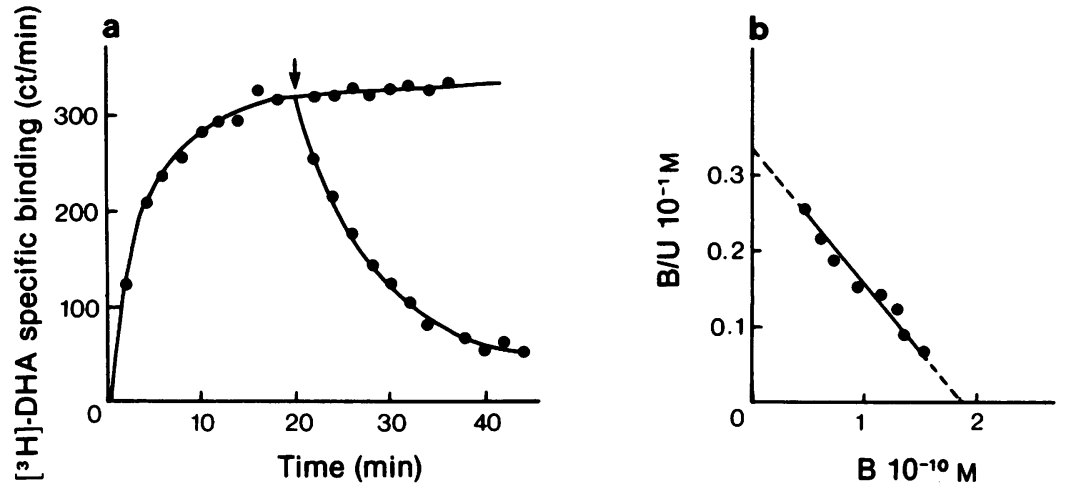

Figure 1 (a) Forward and reverse rates of specific $\left[{ }^{3} \mathrm{H}\right]$-dihydroalprenolol ([ $\left.\left.{ }^{3} \mathrm{H}\right]-\mathrm{DHA}\right)$ binding $\left(3 \times 10^{-9} \mathrm{M}\right)$ to rat cardiac membranes. At the arrow, $(-)$-alprenolol $\left(1 \times 10^{-5} \mathrm{M}\right)$ was added to the incubation mixture containing membranes and $\left[{ }^{3} \mathrm{H}\right]$-DHA. (b) Scatchard analysis of steady state specific binding data at $25^{\circ} \mathrm{C}$ for rat heart membranes with $\left[{ }^{3} \mathrm{H}\right]-\mathrm{DHA}$ concentrations from $2 \times 10^{-9} \mathrm{M}$ to $5 \times 10^{-8} \mathrm{M}$.

washed with $15 \mathrm{ml}$ of incubation buffer $\left(+4^{\circ} \mathrm{C}\right)$. The total time for dilution and filtration was less than 15 seconds. After drying, filters were counted in $10 \mathrm{ml}$ of Permafluor (Packard) in a Packard liquid scintillation counter with an efficiency of $30 \%$. Specific binding was considered as the difference between the radioactivity found on the filters in the absence and presence of a high concentration $\left(10^{-5} \mathrm{M}\right)$ of alprenolol, and usually represented $70 \%$ of total binding to heart membranes. Membrane protein concentrations were determined by the method of Lowry, Rosebrough, Farr \& Randall (1951) bovine serum albumin being used as a standard.

\section{Drugs}

(-)- $\left[{ }^{3} \mathrm{H}\right]$-dihydroalprenolol (specific activity 32.65 $\mathrm{Ci} / \mathrm{mmol}$ ) was purchased from New England Nuclear. The following drugs used in this study were obtained from Sigma: $( \pm)$-isoproterenol $\mathrm{HCl}(( \pm)$-isoprenaline), (-)-isoproterenol- $(+)$-bitartrate ((-)-isoprenaline), (-)-alprenolol- $(+)$-tartrate, $(-)$-adrenaline bitartrate, (-)-noradrenaline $\mathrm{HCl},( \pm)$-propranolol $\mathrm{HCl}$. The following compounds were kindly provided by the manufacturers: practolol $\mathrm{HCl}$ (ICI); Kö $1366 \mathrm{HCl}$; NAB $365 \mathrm{HCl}$; toliprolol $\mathrm{HCl}$ (Boehringer Ingelheim); timolol maleate (Merck, Sharp \& Dohme); pindolol (Sandoz); S $2395 \mathrm{HCl}$ (Servier); metoprolol $\mathrm{HCl}$ (Hässle); acebutolol $\mathrm{HCl}$ (Special); butoxamine $\mathrm{HCl}$ (Burroughs Wellcome Co.); labetolol $\mathrm{HCl}$ (Glaxo) and (+)-isoprenaline-(+)-bitartrate (Aldrich).

\section{Results}

\section{$\left[{ }^{3} \mathrm{H}\right]$-dihydroalprenolol binding parameters}

Time-course study of specific $\left[{ }^{3} \mathrm{H}\right]$-DHA binding to rat heart membranes was performed at $25^{\circ} \mathrm{C}$ using $6 \times 10^{-9} \mathrm{M}$ initial concentration of the labelled ligand. The equilibrium reached a steady state after approximately $20 \mathrm{~min}$ and was maintained up to $90 \mathrm{~min}$, suggesting no marked inactivation of the ligand or loss of binding sites during incubation (Figure 1). When the membrane fraction was incubated with an initial $\left[{ }^{3} \mathrm{H}\right]$-DHA concentration of $6 \times 10^{-9} \mathrm{M}$, the addition of excess (-)-alprenolol $\left(1 \times 10^{-5} \mathrm{M}\right)$ after equilibrium had been obtained, resulted in displacement of bound radioactive alprenolol. Half of the bound $\left[{ }^{3} \mathrm{H}\right]$-DHA was displaced within 6 minutes. The association $\left(k_{1}\right)$ and dissociation rate $\left(k_{-1}\right)$ constants at $25^{\circ} \mathrm{C}$ were slightly different when they were calculated from association and dissociation curves and from two association curves at different concentrations. The first calculation gave $k_{1}=0.633 \times 10^{6}$ $\mathrm{M}^{-1} \mathrm{~s}^{-1}$ and $k_{-1}=0.0017 \mathrm{~s}^{-1}$. The second method resulted in $k_{1}=0.701 \times 10^{6} \mathrm{M}^{-1} \mathrm{~s}^{-1}$, and $k_{-1}=0.0043 \mathrm{~s}^{-1}$.

The concentration dependence of $\left[{ }^{3} \mathrm{H}\right]$-DHA binding was studied with labelled compound concentrations ranging from $2 \times 10^{-9}$ to $5 \times 10^{-8} \mathrm{M}$. Scatchard analysis (Scatchard, 1949) of the data showed a single class of binding sites (Figure 1) characterized by an equilibrium dissociation constant $k_{\mathrm{d}} \simeq 25^{\circ} \mathrm{C}$ of $5.7 \pm 1.1 \times 10^{-9} \mathrm{M}$ (s.d.) and a concentration of $0.18 \pm 0.06 \mathrm{pmol} / \mathrm{mg}$ (s.d.) of membrane protein (mean of 7 experiments). The $k_{\mathrm{d}}$ value indicated by the slope of the Scatchard plot is extremely close to the values $2.7-6.1 \times 10^{-9} \mathrm{M}$ calculated from the ratio $k_{-1} / k_{1}$.

The specificity of $\left[{ }^{3} \mathrm{H}\right]-\mathrm{DHA}$ binding was studied by means of the inhibitory effect of increasing concentrations of catecholamines and adrenoceptor blocking agents (the initial $\left[{ }^{3} \mathrm{H}\right]$-alprenolol concentration being $6 \times 10^{-9} \mathrm{M}$ ). The order of potency of 


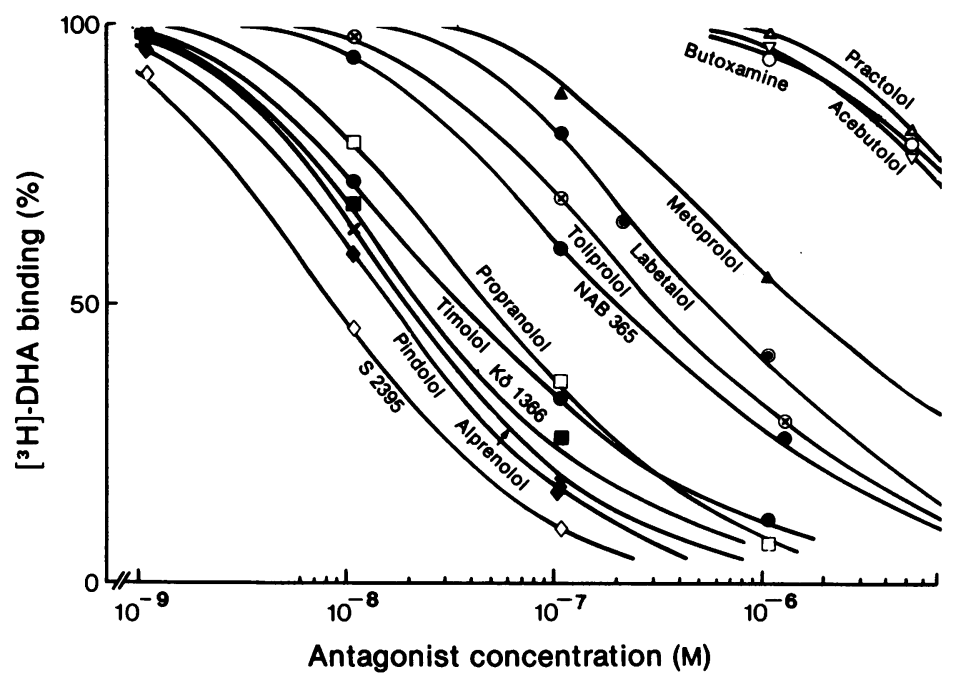

Figure 2 Inhibition of $\left[{ }^{3} \mathrm{H}\right]$-dihydroalprenolol $\left(\left[{ }^{3} \mathrm{H}\right]-\mathrm{DHA}\right)$ specific binding to rat heart membrane $\beta$-adrenoceptors by various $\beta$-blocking agents. All incubations were performed as described in Methods. Data shown are the means of two or three independent duplicate determinations.

agonists in inhibiting $\left[{ }^{3} \mathrm{H}\right]$-DHA binding was $(-)$-isoproterenol $>( \pm)$-isoproterenol $>(+)$-isoproterenol $>(-)$-adrenaline $>(-)$-noradrenaline. Amongst the $13 \beta$-blockers studied (Figure 2) S 2395 appeared to have the most potent inhibitory effect and $( \pm)$-practolol, $( \pm)$-butoxamine and $( \pm)$-acebutolol appeared to be the least efficient compounds in displacing $\left[{ }^{3} \mathrm{H}\right]-$ DHA.

The $\alpha$-agonist, phenylephrine and the $\alpha$-antagonists phenoxybenzamine and phentolamine did not have any inhibitory effect on $\left[{ }^{3} \mathrm{H}\right]$-DHA binding. Labetalol, a competitive adrenoceptor blocking drug at both $\alpha$ - and $\beta$-receptor sites (Agabiti Rosei, Brown, Fraser, Lever, Morron, Robertson \& Trust, 1976) was found to compete with $\left[{ }^{3} \mathrm{H}\right]$-DHA for its binding sites.

The concentrations of drugs causing $50 \%$ displacement of specific binding $\left(\mathrm{EC}_{50}\right)$, calculated from the displacement curves, provide an estimate of the apparent dissociation constant of the drug for the receptor and are inversely related to their affinities. They are indicated in Table 1 with $\mathrm{pA}_{2}$ values reported by Harms (1976) and $K_{B}$ values determined by Kaumann \& Birnbaumer (1974).

\section{Discussion}

The identity of $\left[{ }^{3} \mathrm{H}\right]$-DHA binding sites studied in the present investigation with $\beta$-adrenoceptors is supported by numerous data. The $\left[{ }^{3} \mathrm{H}\right]-\mathrm{DHA}$ binding was characterized by saturability, rapid association and dissociation and high affinity. The binding parameters, and particularly the apparent equilibrium constant $\left(6 \times 10^{-9} \mathrm{M}\right)$ found in rat heart membranes, are very close to those previously reported by Alexander et al. (1975) in canine cardiac membranes where the $K_{\mathrm{d}}$ value appeared to be $7-11 \times 10^{-9} \mathrm{M}$. As previously reported, these binding parameters are highly consistent with the kinetics of isoprenaline-stimulated adenylate cyclase inhibition (Kaumann \& Birnbaumer, 1974). The order of potency for inhibition of binding of the $\beta$-adrenoceptor agonists is in agreement with the $\beta_{1}$ nature of the cardiac $\beta$-receptors (Ahlquist, 1948). This is also supported by the weak affinity of butoxamine, a specific $\beta_{2}$-adrenoceptor antagonist for $\left[{ }^{3} \mathrm{H}\right]-$ DHA binding sites. The specificity of the $\beta$-adrenoceptor binding sites studied here is further demonstrated by the observation that the $\alpha$-blocking agents phentolamine and phenoxybenzamine had no inhibitory effect on $\left[{ }^{3} \mathrm{H}\right]-\mathrm{DHA}$ binding. The classification of the various antagonists according to their respective inhibitory effects leads to two interesting observations. The first one is that metoprolol, acebutolol and practolol which are reported to be cardioselective $\beta$-blockers (Schmitt, 1976) were found to have lower binding site affinities. They are all characterized by a branched-side chain at the aromatic end of the molecule. Their lower affinity for binding sites, as compared to that of the other blockers studied, is perhaps related to steric hindrance by the sidechain. This may interfere with proper spatial relationships between other affinity determining groups 
of the blocker (such as the $\beta-\mathrm{OH}$ group, the cationic head and the aromatic moiety; Harms, 1976) and their counterparts on the receptor. Secondly, when possible, the affinities of the $\beta$-blockers were com- pared with their respective $\mathrm{pA}_{2}$ values based on potency against isoprenaline determined on isolated cardiac preparations (Harms, 1976) and their antagonism to isoprenaline-stimulated adenylate cyclase

Table 1 Pharmacological and biochemical activity of various $\beta$-adrenoceptor blocking agents

$\beta$-Blocking agent

Chemical formula
$( \pm)-2395$

( \pm )-Pindolol

(-)-Alprenolol

(士)-Kö 1366

( \pm ) -Timolol

$\overbrace{}^{\mathrm{N}} \prod_{\mathrm{N}_{-}} \mathrm{N}-\mathrm{CH}_{2}-\mathrm{CHOH}-\mathrm{CH}_{2}-\mathrm{NH}-\mathrm{C}-\left(\mathrm{CH}_{3}\right)_{3}$<smiles>ClOc1cccc2ccccc12</smiles>

(士) - Propranolol

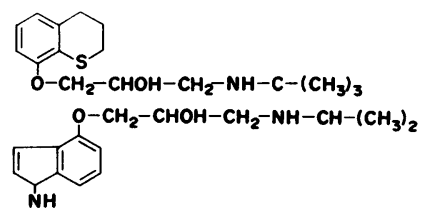

$\mathrm{CH}_{2}-\mathrm{CH}=\mathrm{CH}_{2}$

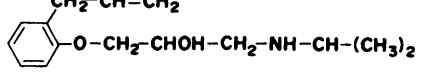

$-\mathrm{ON}-\mathrm{CH}_{2}-\mathrm{CHOH}-\mathrm{CH}_{2}-\mathrm{NH}-\mathrm{C}-\left(\mathrm{CH}_{3}\right)_{3}$

$\beta_{1}-\beta_{2} \quad 2.1 \times 10^{-8}$

$\beta_{1}-\beta_{2} \quad 1.6 \times 10^{-8}$

$\beta_{1}-\beta_{2} \quad 1.8 \times 10^{-8}$

$\beta_{1}-\beta_{2} \quad 3.5 \times 10^{-8}$

$\beta_{1}-\beta_{2} \quad 4.8 \times 10^{-8}$

7.32

8.51

(士) - NAB 365

(士)-Toliprolol

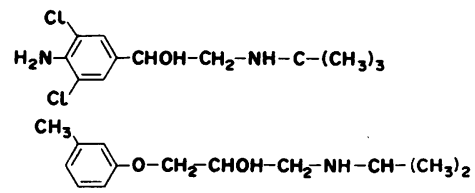

$\beta_{1}-\beta_{2} 2 \times 10^{-7}$

$\beta_{1}-\beta_{2} \quad 2.7 \times 10^{-7} \quad 6.57$

( \pm )-Labetalol<smiles>CC(CCc1ccccc1)NCOCc1ccc(O)c(ON)c1</smiles>$$
\alpha-\beta_{1}-\beta_{2} 5 \times 10^{-7}
$$

(士) -Metoprolol<smiles>COCCc1ccc(OCCOCCNCC(C)(C)C)cc1</smiles>

$\beta_{1} \quad 1.5 \times 10^{-6}$

(士)-Acebutolol

$$
\mathrm{CH}_{3}-\mathrm{CH}_{2}-\mathrm{CH}_{2}-\mathrm{CO}-\mathrm{NH}-2-\mathrm{CH}_{2}-\mathrm{CHOH}-\mathrm{CH}_{2}-\mathrm{NH}-\mathrm{CH}-\left(\mathrm{CH}_{3}\right)_{2} \beta_{1}
$$

$2.3 \times 10^{-5}$

(士) -Practolol<smiles>CC(=O)NCCNCOCCOc1ccc(NC(C)C)cc1</smiles>

$\beta_{1}$

$3.2 \times 10^{-5}$

(士)-Butoxamine

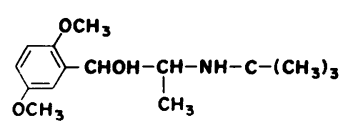$$
\beta_{2} \quad 2.5 \times 10^{-5}
$$

$\mathrm{pEC}_{50}$ : log of the inverse of antagonist concentration causing $50 \%$ maximum displacement. pA of the inverse of antagonist concentration at which agonist concentration must be doubled to achieve the same effect, from Harms (1976). $\mathrm{p} K_{\mathrm{B}}$ : $\log$ of the inverse of apparent affinity constants of interaction of $\beta$-blockers with the adrenoceptor coupled to heart adenylyl cyclase, from Kaumann \& Birnbaumer (1974). 
in cardiac membranes (Kaumann \& Birnbaumer, 1974). Linear regression between either pharmacological value and its respective $\mathrm{pEC}_{50}$ gave surprisingly good correlation. It should be noted that the pharmacological experiments were carried out not in the rat, but in the guinea-pig. However, these excellent correlations provide further evidence for the identity of binding sites with functional $\beta$-receptors. It also sug-

\section{References}

AGABITI ROSEI, E., BROWN, J.J., FRASER, R., LEVER, A.F., MORTON, J.J., ROBERTSON, J.I.S. \& TRUST, P.M. (1976). Labetolol, a competitive alpha- and beta-receptor blocking drug, in the management of hypertension. Aust. N.Z. J. Med., 6, 83-88

AHLQUIST, R.P. (1948). A study of adrenotropic receptors. Am. J. Physiol, 153, 586-600.

ALEXANDER, R.W., WILLIAMS, L.T. \& LEFKOWITZ, R.J. (1975). Identification of cardiac beta-adrenergic receptors by $(-)-\left({ }^{3} \mathrm{H}\right)$ alprenolol binding. Proc. natn Acad. Sci. USA, 72, $1564-1568$.

BROWN, E.M., GARDNER, J.D. \& AURBACH, G.D. (1976). Direct determination of ligand interactions with betaadrenergic receptors on intact turkey erythrocytes: correlation of binding and biological activity. Endocrinology, 99, 1370-1376.

HARDEN, T.K., WOLFE, B.B. \& MOLINOFF, P.B. (1976). Binding of iodinated beta-adrenergic antagonists to proteins derived from rat heart. Mol. Pharmac., 12, $1-15$.

HARMS, H.H. (1976). Isoproterenol antagonism of cardioselective beta-adrenergic receptor blocking agents: a gests that binding experiments could usefully be included in the screening of new compounds reacting with $\beta$-adrenoceptors.

We thank Dr M.A. Devynck for her helpful advice and S. Hamon and E. Ardjoum for typing the manuscript and drawing the figures.

comparative study of human and guinea-pig cardiac and bronchial beta-adrenergic receptors. J. Pharmac. exp. Ther., 199, 329-335.

KAUMANN, A.J. \& BIRNBAUMER, L. (1974). Studies on receptor-mediated activation of adenyl cyclase. IV Characteristics of the adrenergic receptor coupled to myocardial adenylyl cyclase: stereospecificity for ligands and determination of apparent affinity constants for beta-blockers. J. biol. Chem., 249, 7874-7885.

LEFKOWITZ, R.J. \& WILLIAMS, L.T. (1977). Catecholamine binding to the beta-adrenergic receptor. Proc. natn Acad. Sci., USA, 74, 515-519.

LOWRY, O.H., ROSEBROUGH, N.J., FARR, A.L. \& RANDALL, R.J. (1951). Protein measurement with the Folin phenol reagent. J. biol. Chem., 193, 265-275.

SCATCHARD, G. (1949). The attraction of protein for small molecules and ions. Ann. N.Y. Acad. Sci., 51, 660-672.

SCHMITT, H. (1976). Eléments de Pharmacologie. VI Edition. Paris: Flammarion Publ.

(Received October 24, 1977. Revised December 1, 1977.) 